\title{
Epidemiology of sudden unexpected death in infancy in Argentina: secular trend and spatial variation
}

\author{
Valeria F. Chapur, B.S. ${ }^{a}$ Emma L. Alfaro, M.D. ${ }^{a}$, Rubén Bronberg, M.D. ${ }^{b}$ and \\ José E. Dipierri, M.D. ${ }^{a}$
}

a. Institute of

Ecoregions of the

Andes (Instituto

de Ecorregiones

Andinas, INECOA)

- Universidad

Nacional de Jujuy

(UNJu) - National

Scientific and

Technical Research

Council (Consejo

Nacional de

Investigaciones

Científicas y

Técnicas, CONICET)

- High-Altitude

Biology Institute

(Instituto de Biología

de la Altura,

INBIAL), San

Salvador de Jujuy. Argentina.

b. Unit of Medical and Population Genetics, Hospital Ramos Mejía. Buenos Aires,

Argentina.

E-mail address:

Valeria F. Chapur, B.S.:

ferchapur@hotmail.com

\section{Funding:}

Project "Geographic

differentiation

in the Argentine

population structure:

surnames, genetics,

and demographics,"

by the Department of

Science and Technology

and Regional Studies

(Secretaría de Ciencia

y Técnica y Estudios

Regionales, SECTER)

of Universidad

Nacional de Jujuy

(UNJu)

(period 2016-2019).

Conflict of interest:

None.

Received: 5-18-2018

Accepted: 12-10-2018

\begin{abstract}
Introduction. Infant mortality comprises deaths among infants younger than one year old. The proportion of sudden unexpected death in infancy (SUDI) varies by country and based on the cause of death.

Objective. To describe the spatial and temporal variation of SUDI in Argentina between 1991 and 2014 according to the International Classification of Diseases, tenth revision.

Materials and methods. Based on infant death data (provided by the Health Statistics and Information Department), we estimated the percentage of SUDI over the total number of infant deaths and the frequency of causes of death at a provincial, regional, and national level. The risk for death and the secular trend were estimated using a Poisson regression. The SaTScan software, v9.1.1, was used to detect clusters of districts where the percentage of SUDI was significantly different from the national percentage.
\end{abstract}

Results. In Argentina, between 1991 and 2014, 267552 infants younger than 1 year died; $7 \%$ corresponded to SUDI; the secular trend of causes was negative and statistically significant; the risk for SUDI was 0.86, and a great spatial heterogeneity was observed. At a national level, the most common cause was sudden infant death syndrome, with inter-regional differences. In nine district clusters, the risk for SUDI ranged between 4.36 and 1.24, which is significantly different from the rest of the country.

Conclusions. The proportion of SUDI and its causes show inter-regional heterogeneity; codes related to inaccurate diagnoses predominated in more unfavorable regions, while sudden infant death syndrome was prevalent in the more developed regions.

Key words: sudden unexpected infant death, epidemiology, secular trend, risk factors, Argentina.

http:/ / dx.doi.org/10.5546/ aap.2019.eng.164

To cite: Chapur VF, Alfaro EL, Bronberg R, Dipierri JE. Epidemiology of sudden unexpected death in infancy in Argentina: secular trend and spatial variation. Arch Argent Pediatr 2019;117(3):164-170.

\section{INTRODUCTION}

The concept of sudden death was first proposed in 1956 in relation to the death of a child in apparent good health without perspective of such fatal outcome. Later, sudden infant death syndrome (SIDS) was defined as the sudden death of a child younger than 1 year old that could not be explained after a thorough investigation, including a complete autopsy, an examination of the death scene, and a medical record review. ${ }^{1,2}$

Recently, and based on the indication of the cause of death in death certificates according to the International Classification of Diseases, tenth revision (ICD-10), ${ }^{3}$ Taylor et al. ${ }^{4}$ have used the category sudden unexpected death in infancy (SUDI), which includes SIDS under code R95, together with accidental suffocation and strangulation in bed (W75), inhalation of gastric contents (W78), inhalation and ingestion of food causing obstruction of respiratory tract (W79), other sudden death of natural or unnatural equivocal disease, including that for which no autopsy was done (R96), ${ }^{5}$ unattended death (R98), and other ill-defined and unspecified causes of mortality (R99).6,7,4 Based on this proposal, clearly medical causes (infection, metabolic disorder, arrhythmia, congenital anomaly) or forensic causes (trauma or lesion) are excluded, even if they initially present as SUDI.

In this study, we describe the spatial and temporal variation of SUDI in Argentina based on death certificates according to ICD-10 component codes. 


\section{MATERIALS AND METHODS}

This was a retrospective, population study based on the data for infant deaths occurred in Argentina between 1991 and 2014 (provided by the Health Statistics and Information Department of the National Ministry of Health).

Outcome measures were the total number of deaths of infants younger than 1 year old and the number of deaths by cause included under SUDI (R95, R96, R98, R99, W75, W78 + W79). ${ }^{4}$ The percentage of SUDI over the total number of infant deaths and the frequency of component causes at a provincial, regional, and national level were estimated. Geographic regions corresponded to the Northwest region of Argentina (NOA: Jujuy, Salta, Tucumán, Santiago del Estero, Catamarca, and La Rioja); Northeast region of Argentina (NEA: Formosa, Chaco, Misiones, and Corrientes); Cuyo (San Luis, San Juan, and Mendoza); Central Region (Córdoba, Santa Fe, Entre Ríos, Buenos Aires, La Pampa, and Autonomous City of Buenos Aires), and Patagonia (Neuquén, Río Negro, Santa Cruz, Chubut, and Tierra del Fuego).
Given the extension of the study period, the codes included under SUDI according to the ICD-10 and the ninth-revision equivalents were used. For time analysis, the total period was subdivided into three intervals: 1991-1998, 1999-2006, and 2007-2014. The secular trend (ST) for the entire period and the variation in the risk for death for the 2007-2014 subperiod compared to the baseline period (1991-1998) were estimated using the Poisson regression model (Stata 12.1) considering infants who died due to SUDI as a dependent outcome measure, time units as independent outcome measures, and total deceased infants as the exposure outcome measure, as required by the model.

The spatial analysis was done using the SatScan v9.1.18 software based on the number of SUDIs (group of cases), the total number of deceased infants (population), and the geographic coordinates of each district; geographic areas were determined based on proportions that were statistically different from the national average $(p<0.05)$.

TABLE 1. Number of deaths, percentage of sudden unexpected death in infancy, and confidence interval by cause, by region, and for the country over the total study period

\begin{tabular}{|c|c|c|c|c|c|c|c|}
\hline Cause & & Central Region & Cuyo & NEA & NOA & Patagonia & Argentina \\
\hline \multicolumn{8}{|l|}{ R95 } \\
\hline & $\mathrm{N}$ & 5405 & 228 & 809 & 722 & 710 & 7874 \\
\hline & $\%$ & 51 & 19 & 35 & 23 & 60 & 43 \\
\hline & $\mathrm{CI}$ & $50-52$ & $14-24$ & $31-38$ & $20-26$ & $56-63$ & $41-44$ \\
\hline \multirow[t]{3}{*}{ R96 } & $\mathrm{N}$ & 34 & 1 & 43 & 33 & 13 & 124 \\
\hline & $\%$ & 0.3 & 0.08 & 2 & 1 & 1 & 1 \\
\hline & $\mathrm{CI}$ & $-2-2$ & $-6-6$ & $-2-6$ & $-2-5$ & $-5-7$ & $-1-2$ \\
\hline \multirow[t]{3}{*}{ R98 } & $\mathrm{N}$ & 104 & 9 & 42 & 584 & 53 & 792 \\
\hline & $\%$ & 1 & 1 & 2 & 19 & 4 & 4 \\
\hline & $\mathrm{CI}$ & $-1-3$ & $-5-6$ & $-2-6$ & $16-22$ & $-1-1$ & $3-6$ \\
\hline \multirow[t]{3}{*}{ R99 } & $\mathrm{N}$ & 2009 & 23 & 1058 & 1174 & 81 & 4345 \\
\hline & $\%$ & 19 & 2 & 45 & 38 & 7 & 24 \\
\hline & $\mathrm{CI}$ & $17-21$ & $-4-7$ & $42-48$ & $35-41$ & $1-12$ & $22-25$ \\
\hline \multirow[t]{3}{*}{ W75 } & $\mathrm{N}$ & 46 & 39 & 22 & 97 & 44 & 248 \\
\hline & $\%$ & 0.4 & 3 & 1 & 3 & 4 & 1 \\
\hline & $\mathrm{CI}$ & $-1-2$ & $-3-9$ & $-3-5$ & $-0.3-7$ & $-2-9$ & $-0.08-2$ \\
\hline \multirow[t]{3}{*}{ W78-W79 } & $\mathrm{N}$ & 3032 & 912 & 364 & 476 & 286 & 5070 \\
\hline & $\%$ & 28 & 75 & 15 & 15 & 24 & 27 \\
\hline & CI & $27-30$ & $72-78$ & $12-19$ & $12-19$ & 19-29 & $26-29$ \\
\hline
\end{tabular}

CI: confidence interval; NEA: Northeast region of Argentina; NOA: Northwest region of Argentina.

R95: sudden infant death syndrome. R96: other sudden death. cause unknown. R98: unattended death.

R99: other ill-defined and unspecified causes of mortality. W75: accidental suffocation and strangulation in bed.

W78: inhalation of gastric contents. W79: inhalation and ingestion of food causing obstruction of respiratory tract. 


\section{RESULTS}

In the 1991-2014 period, 267552 infant deaths were recorded; of these, 18453 corresponded to SUDI.

It accounted for $7 \%$ of all infant deaths, with varied proportions among component causes. Table 1 shows the percentage of each of these causes in Argentina and in each region. At a national level, the most frequent cause was R95, followed by W78 + W79, R99, R98, W75, and R96; however, disparities were observed at a regional level (Table 1). Whereas the most common cause in the Central Region and Patagonia was R95, in the NEA and NOA, it was R99, and in Cuyo, $75 \%$ of SUDI corresponded to W78 + W79 (Table 1).

The regions with a SUDI percentage equal to or lower than the national percentage were the Central Region, Cuyo, NEA, and NOA. The opposite was observed in Patagonia, where $10 \%$ of deaths corresponded to SUDI (Table 2). At a national level, the percentage of SUDI decreased gradually and showed a negative, significant ST of $10 \%$ throughout the period, as observed in the NEA (10\%), NOA (42\%), and Patagonia (41\%), whereas in the Central Region and Cuyo, the ST was positive, although not statistically significant.

Compared to the 1991-1998 period, the risk for SUDI in the 2007-2014 period was 0.86 at a national level. At a regional level, a significantly higher risk was noted in the Central Region, followed by Cuyo, NEA, NOA, and Patagonia (Table 2). In the last period, the highest percentages of SUDI were recorded in Tierra del Fuego (11.1\%), Neuquén (8.3\%), and Buenos

TABLE 2. Percentage of sudden unexpected death in infancy by period, secular trend and risk by region

\begin{tabular}{lcccccccc}
\hline & $\mathbf{1 9 9 1 - 1 9 9 8}$ & $\mathbf{1 9 9 9 - 2 0 0 6}$ & $\mathbf{2 0 0 7 - 2 0 1 4}$ & $\mathbf{1 9 9 1 - 2 0 1 4}$ & Secular trend & $\boldsymbol{p}$ & Risk & $\boldsymbol{p}$ \\
\hline Central Region & 6.9 & 6.9 & 7.1 & 7.0 & 0.001 & 0.658 & 1.03 & 0.203 \\
Cuyo & 6.2 & 6.1 & 6.8 & 6.3 & 0.005 & 0.230 \\
NEA & 6.1 & 5.5 & 5.1 & 5.7 & $-0.010^{*}$ & 0.002 & $0.84^{*}$ & 0.002 \\
NOA & 9.3 & 6.2 & 4.4 & 7.1 & $-0.042^{*}$ & 0.000 & $0.47^{*}$ & 0.000 \\
Patagonia & 13.3 & 9.8 & 6.3 & 10.3 & $-0.041^{*}$ & 0.000 & $0.47^{*}$ & 0.000 \\
Country & 7.4 & 6.6 & 6.4 & 6.9 & $-0.010^{*}$ & 0.000 & $0.86^{*}$ & 0.000 \\
\hline
\end{tabular}

* Statistically significant differences, $\mathrm{p}<0.05$.

NEA: Northeast region of Argentina; NOA: Northwest region of Argentina.

TABLE 3. Percentage of sudden unexpected death in infancy, secular trend and risk by province

\begin{tabular}{|c|c|c|c|c|c|c|c|}
\hline$\underline{\text { Province }}$ & 1991-1998 & 1999-2006 & 2007-2014 & Secular trend & $p$ & Risk & $p$ \\
\hline Buenos Aires & 7.0 & 7.4 & 8.2 & $0.008^{*}$ & 0.000 & $1.17^{*}$ & 0.000 \\
\hline CABA & 2.8 & 1.4 & 1.0 & $-0.065^{*}$ & 0.000 & $0.36^{*}$ & 0.000 \\
\hline Catamarca & 8.4 & 8.1 & 7.0 & -0.006 & 0.547 & 0.83 & 0.279 \\
\hline Chaco & 4.3 & 5.7 & 7.1 & $0.035^{*}$ & 0.000 & $1.65^{*}$ & 0.000 \\
\hline Chubut & 14.4 & 8.2 & 2.6 & $-0.081^{*}$ & 0.000 & $0.21^{*}$ & 0.000 \\
\hline Córdoba & 8.7 & 6.5 & 4.2 & $-0.042^{*}$ & 0.000 & $0.48^{*}$ & 0.000 \\
\hline Corrientes & 5.8 & 5.4 & 3.7 & $-0.025^{*}$ & 0.000 & $0.64^{*}$ & 0.000 \\
\hline Entre Ríos & 6.7 & 6.3 & 7.9 & -0.004 & 0.503 & 1.18 & 0.106 \\
\hline Formosa & 7.9 & 3.7 & 4.0 & $-0.052^{*}$ & 0.000 & $0.50^{*}$ & 0.000 \\
\hline Jujuy & 18.6 & 10.3 & 4.4 & $-0.077^{*}$ & 0.000 & $0.24^{*}$ & 0.000 \\
\hline La Pampa & 12.1 & 7.0 & 5.5 & $-0.045^{*}$ & 0.000 & $0.46^{*}$ & 0.001 \\
\hline La Rioja & 3.7 & 6.2 & 4.8 & $0.030^{*}$ & 0.020 & 1.46 & 0.104 \\
\hline Mendoza & 4.9 & 6.9 & 7.8 & $0.025^{*}$ & 0.000 & $1.58^{*}$ & 0.000 \\
\hline Misiones & 7.6 & 6.7 & 5.2 & $-0.021^{*}$ & 0.000 & $0.68^{*}$ & 0.000 \\
\hline Neuquén & 14.6 & 10.1 & 8.3 & $-0.040^{*}$ & 0.000 & $0.57^{*}$ & 0.000 \\
\hline Río Negro & 11.8 & 11.5 & 6.6 & $-0.027^{*}$ & 0.000 & $0.56^{*}$ & 0.000 \\
\hline Salta & 10.1 & 6.6 & 5.3 & $-0.036^{*}$ & 0.000 & $0.52^{*}$ & 0.000 \\
\hline San Juan & 7.2 & 2.8 & 4.4 & $-0.034^{*}$ & 0.000 & $0.61^{*}$ & 0.001 \\
\hline San Luis & 9.1 & 10.0 & 7.2 & -0.010 & 0.290 & 0.80 & 0.192 \\
\hline Santa Cruz & 13.1 & 7.3 & 6.5 & $-0.032^{*}$ & 0.009 & $0.50^{*}$ & 0.001 \\
\hline Santa Fe & 6.2 & 8.6 & 7.6 & $0.013^{*}$ & 0.001 & $1.23^{*}$ & 0.004 \\
\hline Santiago del Estero & 15.2 & 9.9 & 7.4 & $-0.048^{*}$ & 0.000 & $0.49^{*}$ & 0.000 \\
\hline Tierra del Fuego & 10.5 & 12.0 & 11.1 & 0.006 & 0.735 & 1.38 & 0.696 \\
\hline Tucumán & 2.0 & 2.2 & 1.4 & 0.003 & 0.740 & 0.83 & 0.295 \\
\hline
\end{tabular}

* Statistically significant differences, $\mathrm{p}<0.05$.

CABA: Autonomous City of Buenos Aires. 
Aires $(8.2 \%)$. Among the 24 provinces, a ST without significant variations was observed only in 4 (Catamarca, Entre Ríos, San Luis, and Tierra del Fuego); the most steep reductions were observed in Chubut and Jujuy. The highest risk was seen in Chaco, Mendoza, and La Rioja, although it was not statistically significant in the latter (Table 3).

The risk for SUDI by district shows 9 clusters with significantly different values compared to the total for the country (Figure 1, Annex). The cluster with the highest risk (4.36) included districts of Jujuy and Salta, whereas the cluster with the lowest risk (1.24) corresponded to most districts of Santa Fe and Córdoba, two of Entre Ríos, and one of Santiago del Estero.

Table 4 shows the component causes of SUDI for each cluster. The most common cause was R95 (SIDS) in clusters 4, 5, 6, and 9; followed by R99, which mainly focused on Santiago del Estero and some districts of other NOA provinces (clusters 2, 3 , and 7). Other relevant causes were R98 in the high-altitude districts of Salta and Jujuy, and W78 + W79 in the Cuyo region and in Córdoba and La Rioja.

\section{DISCUSSION}

The ICD does not contain a specific code for SUDI; according to Taylor et al., ${ }^{4}$ it corresponds to a heterogeneous but well-defined set of causes of death, either explained or not, that may be collected from infant death reports.

This is the first study that examines the extent of SUDI, its risk and trends in Argentina.

By describing the causes of SUDI, we observe a great inter-regional heterogeneity in the contribution of each cause. The causes for codes
W78 + W79 predominate in Cuyo and are related to an inadequate newborn care, a prone sleeping position, inhalation or aspiration of food or gastric contents, etc., which obstruct breathing while the infant is lying down.

In the NOA and NEA, the prevalent cause is R99, which is usually associated with an inadequate diagnosis, lack of adequate medical

FIGURE 1. Clusters by risk for sudden unexpected death in infancy

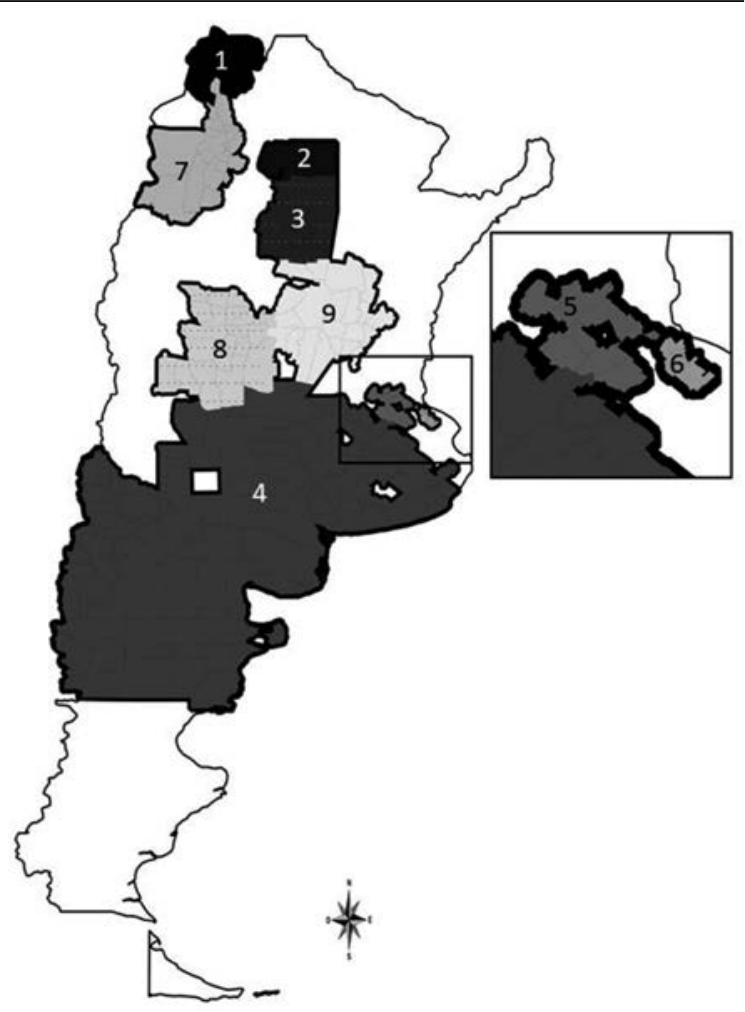

TABLE 4. Risk in each cluster and percentage of sudden unexpected death in infancy components

\begin{tabular}{|c|c|c|c|c|c|c|c|}
\hline Cluster & Risk & R95 & R96 & R98 & R99 & W75 & W78 + W79 \\
\hline 1 & 4.36 & 9 & 1 & 63 & 17 & 2 & 8 \\
\hline 2 & 2.67 & 8 & 0 & 13 & 78 & 0 & 1 \\
\hline 3 & 2.27 & 16 & 0 & 14 & 67 & 2 & 2 \\
\hline 4 & 1.68 & 64 & 1 & 2 & 11 & 2 & 2 \\
\hline 5 & 1.57 & 56 & 0 & 0 & 14 & 0 & 30 \\
\hline 6 & 1.50 & 63 & 0 & 0 & 22 & 0 & 14 \\
\hline 7 & 1.36 & 26 & 1 & 4 & 40 & 6 & 22 \\
\hline 8 & 1.25 & 34 & 0 & 2 & 6 & 1 & 57 \\
\hline 9 & 1.24 & 49 & 0 & 7 & 23 & 0 & 20 \\
\hline
\end{tabular}

The Annex shows, in detail, the districts included in each cluster.

R95: sudden infant death syndrome. R96: other sudden death, cause unknown. R98: unattended death.

R99: other ill-defined and unspecified causes of mortality. W75: accidental suffocation and strangulation in bed.

W78: inhalation of gastric contents. W79: inhalation and ingestion of food causing obstruction of respiratory tract. 
care or inaccurate staff certification at health centers. $^{9}$

One of the limitations of SUDI identification based on death certificates is the heterogeneity in the quality of investigations related to such death. There is no certainty, especially in Argentina, about the fact that causes assigned to R95 effectively comply with the requirements of this code. ${ }^{10,11}$ If the protocol is not followed, it is very difficult to distinguish between SIDS and other causes of SUDI. In our country, the statistical report of deaths is limited to documenting sudden deaths but the restricted criteria used to define them are not characterized. ${ }^{10}$

Notwithstanding these limitations, the percentage of deaths due to SIDS in Argentina is similar to that reported in countries with better conditions for diagnostic criteria compliance, ${ }^{4,7}$ where the proportion of autopsies ranges between $78 \%$ and $85 \% .{ }^{12,13}$

Figure 2 shows a comparison of the causes of SUDI in Argentina and other countries selected by Taylor et al., (Australia, England, Germany, Japan, the Netherlands, New Zealand, and the United States of America) for the same period (2002-2010) and component of infant mortality (post-neonatal deaths). The percentages of R95 and $\mathrm{R} 99$ in Argentina are similar to those in other countries, although W78 + W79 are overrepresented. Almost $20 \%$ of SUDI in Argentina correspond to these causes, and this percentage widely exceeds the values observed in other countries $(0.7 \%$ to $8 \%)$.

The requirement of an autopsy and the corresponding investigation of deaths for the SIDS diagnosis results in an over-representation of the R96 code in Japan, where autopsies are done in only $30 \%$ of cases, thus reducing the representation of R95. ${ }^{14}$ In Argentina, and in agreement with the rest of the countries, the R96 code is practically unrepresented.

The risk factors associated with SIDS (sleeping position, inadequate bedding, and co-sleeping) may vary depending on the population culture and impact SUDI percentage differentially. ${ }^{10,15-17}$ According to the National Program for the Prevention of Sudden Infant Death, in 2010, $59.5 \%$ of infants slept in the supine position; $37.9 \%$, on their side; and $2.5 \%$, on their stomach. ${ }^{11}$ A study conducted in a hospital of Buenos Aires confirmed a reduction, between 1996 and 2006, in the percentage of children who slept on their stomach, although the prevalence of the supine position was below $10 \% .^{18}$

Other risk factors for SIDS and SUDI include smoking, adolescent pregnancy, a low maternal

FIGURE 2. Percent distribution of sudden unexpected death in infancy components by selected country

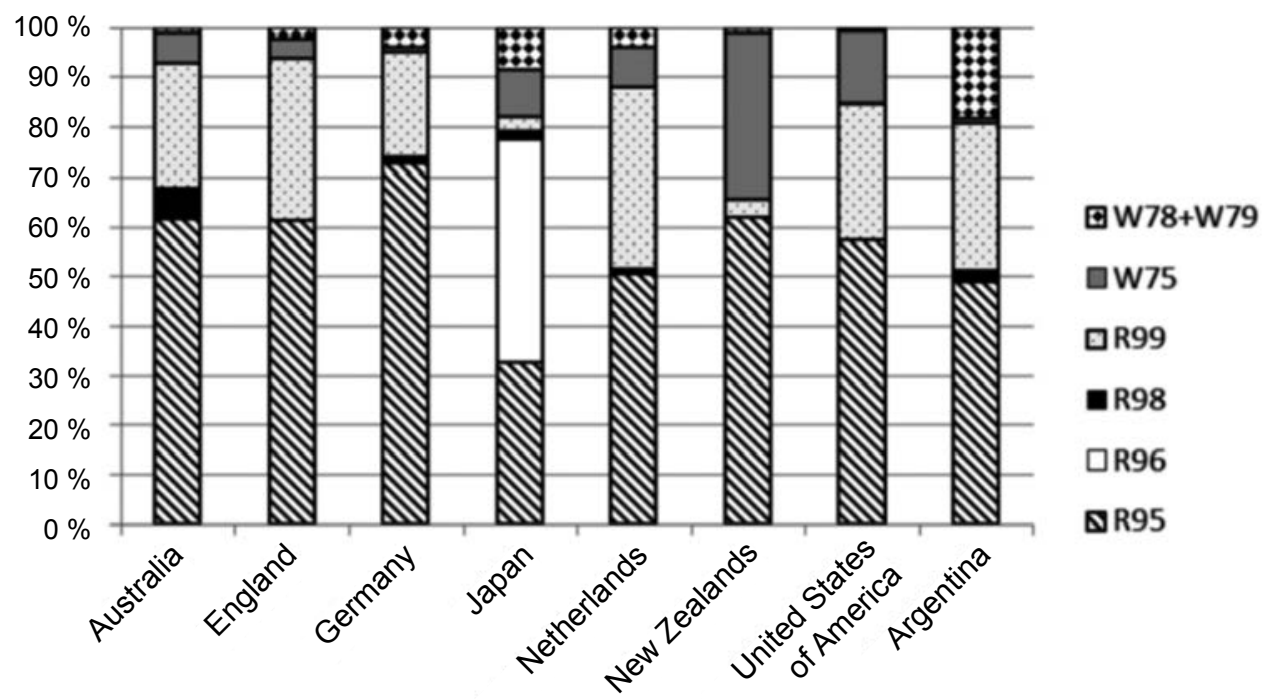

Source: Taylor et al. ${ }^{4}$ for Australia, England, Germany, Japan, the Netherlands, New Zealand, and the United States of America. Own data for Argentina.

R95: sudden infant death syndrome. R96: other sudden death, cause unknown. R98: unattended death.

R99: other ill-defined and unspecified causes of mortality. W75: accidental suffocation and strangulation in bed.

W78: inhalation of gastric contents. W79: inhalation and ingestion of food causing obstruction of respiratory tract. 
socioeconomic or education level, being a single mother, lack of or reduced antenatal care and controls, lack of or reduced breastfeeding. ${ }^{11,15,16,19}$ In Bariloche, out of 10 cases of SUDI that underwent an autopsy, $50 \%$ of mothers smoked and $70 \%$ of infants slept on their side. ${ }^{10}$ In maternity centers of Pilar (province of Buenos Aires), between 2011 and 2012, a significant reduction was observed in compliance with SIDS prevention recommendations, especially in relation to mothers who were young, had a low level of education, were single, and had unmet basic needs. ${ }^{20}$

Although, in Argentina, several public campaigns have been launched to inform and raise awareness in the population about the risk factors for and child rearing practices associated with SUDI, the reduction would be even greater considering that most of SUDI causes are easily preventable. ${ }^{21}$ Even though, in some regions and provinces, the percentage of SUDI shows a negative ST, in the Central Region and Cuyo, the ST is positive and, although not significant, it is seen in the most populated regions that have a high socioeconomic development.

The high frequency of R99 observed in the NOA fades out once a cluster analysis is done because some districts in Jujuy and Salta show the highest risk at a national level (4.36), and there R98 predominates, which is defined by the Pan-American Health Organization (PAHO) ${ }^{9}$ as unknown cause of death due to lack of medical care. In general, this code is related to inequalities in the access to the health system, which is seen in these populations living in high-altitude locations, rugged geographies or low population density, which are barriers to health center access. ${ }^{22}$

The second and third clusters (2.67 and 2.27 risks) comprise districts of Santiago del Estero, where the mean annual temperature is very high, with peak temperatures above $45{ }^{\circ} \mathrm{C}$ between November and February. To a certain extent, the high temperatures may account for a greater risk for SUDI, because an infant's thermoregulatory ability is sensitive to increases in the environment temperature and in the house interior temperature during the summer. ${ }^{23}$ However, the most common code in these clusters is R99, which, as mentioned above, would indicate an inadequate cause of death recording.

In addition to the risk factors mentioned before, SIDS is associated with other environmental risk factors. The association between SUDI and a higher risk is seen in districts of Salta and Jujuy that are located more than 2000 meters above sea level (MASL). This is consistent with the evidence that altitude is independently associated with SIDS and that postnatal hypoxia plays a major role in the pathogenesis of this syndrome. ${ }^{24}$ In San Antonio de los Cobres, between 1996 and 2001, $36 \%$ of infant deaths were recorded under the R95 code and infants who had a polysomnography showed significant oxygen saturation reductions during sleep (up to $67 \%$ ). ${ }^{25}$ In addition to hypobaric hypoxia, high-altitude environments have a series of risk factors for SUDI, both environmental (thermal variability and extreme cold) and cultural (co-sleeping, wood-burning heating, poor ventilation). Among the latter, it is worth noting aguayo, a knitted fabric originally used for warmth, which is now used to carry the baby or transport objects in the north of Argentina, Bolivia, and Peru. In relation to SUDI, the use of aguayo would constitute an imperfect cultural adaptation to an extreme environment because, even though it does protect the baby from environmental factors, it may be at the high expense of exposing it to additional stressors, like higher levels of carbon dioxide from the aguayo microenvironment. ${ }^{26}$

Most likely, the highest risk for infant and postneonatal mortality, observed by Chapur et al. ${ }^{22}$ in the NOA districts that are located more than 2000 MASL compared to the rest of the region, is due to SUDI and the fact that many unexplained causes correspond to the erroneous recording of $\mathrm{R} 95$.

The main weaknesses of this study are the disparity in criteria used to assign the cause of death due to SUDI and that no protocol was implemented to assign a specific SIDS diagnosis. The strengths of this study are based on its long study period and spatial coverage of data used to describe SUDI. As reported, SUDI causes, in spite of being uncommon, could, most of the times, be easily reduced with adequate health campaigns.

\section{CONCLUSIONS}

The number of SUDIs reduced during the study period. The proportion of SUDI and its component causes showed inter-regional heterogeneity; the codes related to inaccurate diagnoses predominated in the more unfavorable regions, while SIDS was prevalent in the more developed regions, which was consistent with the general pattern observed in countries included 
in the comparison. This evidences the need to implement differential preventive actions and provide training aimed at complying with protocol, diagnosis, and SUDI recording to prevent inaccurate coding.

\section{REFERENCES}

1. Mitchell EA, Krous HF. Sudden unexpected death in infancy: a historical perspective. J Paediatr Child Health. 2015; 51(1):108-12.

2. Rossato N. Síndrome de Muerte Súbita del Lactante: De la teoría a la práctica diaria. Clín Pediatr Sur (Montev). 2010; 3(4):65-82.

3. Organización Panamericana de la Salud. Clasificación estadística internacional de enfermedades y problemas relacionados conla salud.(CIE-10). Manual deinstrucciones. 10ma rev. Volumen 2. Washington, DC.: OPS; 2003.

4. Taylor BJ, Garstang J, Engelberts A, Obonai T, et al. International comparison of sudden unexpected death in infancy rates using a newly proposed set of cause-of-death codes. Arch Dis Child. 2015; 100(11):1018-23.

5. Krous HF, Beckwith JB, Byard RW, Rognum TO, et al. Sudden infant death syndrome and unclassified sudden infant deaths: a definitional and diagnostic approach. Pediatrics. 2004; 114(1):234-8.

6. Shapiro-Mendoza CK, TomashekKM, Anderson RN, Wingo J. Recent national trends in sudden, unexpected infant deaths: moreevidence supporting a change in classification or reporting. Am J Epidemiol. 2006; 163(8):762-9.

7. Matthews TJ, MacDorman MF, Thoma ME. Infant Mortality Statistics From the 2013 Period Linked Birth/Infant Death Data Set. Natl Vital Stat Rep. 2015; 64(9):1-30.

8. Kulldorff M, Huang L, Konty K. A scan statistic for continuous data based on the normal probability model. Int J Health Geogr. 2009; 8:58.

9. Organización Panamericana de la Salud. Estadísticas de salud de las Américas. Washington, D.C: OPS; 2003.

10. Gil L, Herbón F, Little A, López M, et al. Investigación de las causas de muerte súbita e inexplicable en niños menores de un año en la ciudad de Bariloche y aledaños. Arch Argent Pediatr. 2008; 106(6):518-23.

11. Jenik A, Grad E, Orazi V, Sapoznicoff L, et al. Consideraciones sobre el sueño seguro del lactante. Grupo de Trabajo en Muerte Súbita e Inesperada del Lactante de la Sociedad Argentina de Pediatría. [Accessed on: April $1^{\text {st }}$ 2018]. Available at: http://www.sap.org.ar/docs/ profesionales/consensos/consideracionesSueno.pdf.

12. Carpenter RG, Irgens LM, Blair PS, England PD, et al. Sudden unexplained infant death in 20 regions in Europe: case control study. Lancet. 2004; 363(9404):185-91.

13. Winkel BG, Holst AG, Theilade J, Kristensen IB, et al. Sudden unexpected death in infancy in Denmark. Scand Cardiovasc J. 2011; 45(1):14-20.
14. Sawaguchi T, Fujita T, Sawaguchia A, Nishida H. The epidemiological study on registered cases of sudden infant death syndrome (SIDS) in Tokyo: examination of the effect of autopsy on diagnosis of SIDS and the mortality statistics in Japan. Forensic Sci Int. 2000; 109(1):65-74.

15. VázquezLópezL.Síndrome dela muerte súbita del lactante: Epidemiología: Factores de riesgo. Actuación sobre dichos factores. In: V Simposium Nacional Sobre Síndrome de la Muerte Súbita del Lactante. June $17^{\text {th }}, 2004$. Madrid, Spain. 2004;21-3. [Accessed on: December 11 ${ }^{\text {th }}, 2018$ ]. Available at: www.infocefalia.com/Simposium_msl_2004.pdf.

16. Shapiro-Mendoza CK, Colson ER, Willinger M, Rybin DV, et al. Trends in Infant Bedding Use: National Infant Sleep Position Study, 1993-2010. Pediatric. 2015; 135(1):10-7.

17. Parks SE, Erck Lambert AB, Shapiro-Mendoza CK. Racial and Ethnic Trends in Sudden Unexpected Infant Deaths: United States, 1995-2013. Pediatrics. 2017; 139(6):e20163844.

18. Eymann A, Ricciardi M, Caprotta G, Fustiñana C, et al. Cambios en la posición al dormir para la prevención de la muerte súbita del lactante: diez años de seguimiento. $A n$ Pediatr (Barc). 2008; 68(3):244-9.

19. Pérez Rodríguez J. Etiopatogenia: avances en las investigaciones sobre el SMSL principales hipótesis actuales. In: V Simposium Nacional Sobre Síndrome de la Muerte Súbita del Lactante. June $17^{\text {th }}, 2004$. Madrid, Spain. 2004;15-20. [Accessed on: December 11 $1^{\text {th }}, 2018$ ]. Available at: www.infocefalia.com/Simposium_msl_2004.pdf.

20. Rocca RM, BoschFJ,HensonDC, Reyes HP, etal.Evaluación de la adherencia a las recomendaciones para disminuir el riesgo de Síndrome de muerte súbita del lactante. Rev Chil Pediatr. 2014; 85(4):462-9.

21. Ministerio de Salud de la Nación, Sociedad Argentina de Pediatría. Mortalidad Infantil según Criterios de Reducibilidad. 3.ra rev. 2014;3(56). [Accessed on: January $\left.20^{\text {th }}, 2015\right]$. Available at: http://www.msal.gov.ar/ images/ stories / bes / graficos / 0000000193 cnt-s03-criteriosreducibilidad.pdf.

22. Chapur VF, Alfaro EL, Bronberg R, Dipierri JE. Relación de la mortalidad infantil con la altura geográfica en el Noroeste Argentino. Arch Argent Pediatr. 2017; 115(5):462-9.

23. Jhun I, Mata DA, Nordio F, Lee M, et al. Ambient Temperature and Sudden Infant Death Syndrome in the United States. Epidemiology. 2017; 28(5):728-34.

24. Katz D, Shore S, BandleB, Niermeyer S, et al. Sudden infant death syndrome and residential altitude. Pediatrics. 2015; 135(6):e1442-9.

25. Alduncin J, Grañana N, FollettF, MusanteG, etal. Problemas respiratorios durante el sueño en lactantes nativos del altiplano argentino. Arch Argent Pediatr. 2005; 103(1):14-22.

26. Tronick EZ, Thomas RB, Daltabuit M. The Quechua Manta Pouch: A Caretaking Practice for Buffering the Peruvian Infant against the MultipleStressors of High Altitude. Child Dev. 1994; 65(4):1005-13. 


\section{ANNEX}

\section{Clusters by risk for sudden unexpected death in infancy}

\begin{tabular}{|c|c|c|}
\hline Cluster & Districts & Risk \\
\hline 1 & $\begin{array}{l}\text { Cochinoca, Humahuaca, Rinconada, Santa Catalina, Susques, Tilcara, Tumbaya, Valle Grande, } \\
\text { Yavi (PROVINCE OF JUJUY); Iruya, Santa Victoria (PROVINCE OF SALTA) }\end{array}$ & 4.36 \\
\hline 2 & Alberdi, Copo, Pellegrini (PROVINCE OF SANTIAGO DEL ESTERO) & 2.67 \\
\hline 3 & $\begin{array}{l}\text { Aguirre, Atamisqui, Avellaneda, Belgrano, Figueroa, General Taboada, Juan F. Ibarra, Loreto, } \\
\text { Mitre, Moreno, Ojo de Agua, Quebrachos, Robles, Salavina, San Martín, Sarmiento, Silipica } \\
\text { (PROVINCE OF SANTIAGO DEL ESTERO) }\end{array}$ & 2.27 \\
\hline 4 & $\begin{array}{l}25 \text { de Mayo, } 9 \text { de Julio, Adolfo Alsina, Adolfo Gonzales Chaves, Ayacucho, Azul, Bahía Blanca, } \\
\text { Balcarce, Benito Juárez, Bolivar, Bragado, Carlos Tejedor, Coronel de Marina L. Rosales, Coronel } \\
\text { Dorrego, Coronel Pringles, Coronel Suárez, Daireaux, Florentino Ameghino, General Alvarado, } \\
\text { General Alvear, General La Madrid, General Pinto, General Pueyrredón, General Viamonte, } \\
\text { General Villegas, Guaminí, Hipólito Yrigoyen, Laprida, Las Flores, Leandro N. Alem, Lincoln, } \\
\text { Lobería, Maipú, Mar Chiquita, Necochea, Olavarría, Patagones, Pehuajó, Pellegrini, Puán, } \\
\text { Rauch, Rivadavia, Saavedra, Saladillo, Salliquelo, San Cayetano, Tandil, Tapalqué, Tornquist, } \\
\text { Trenque Lauquen, Tres Arroyos, Tres Lomas, Villarino (PROVINCE OF BUENOS AIRES); Biedma, } \\
\text { Cushamen, Florentino Ameghino, Futaleufú, Gaiman, Gastre, Languiñeo, Paso de Indios, } \\
\text { Rawson, Tehuelches, Telsen (PROVINCE OF CHUBUT); General Roca, Presidente Roque Sáenz } \\
\text { Peña (PROVINCE OF CÓRDOBA); Atreucó, Capital, Catriló, Chalileo, Chapaleufú, Chical Co, } \\
\text { Conhelo, Guatrache, Hucal, Loventué, Maraco, Puelén, Quemú Quemú, Rancul, Realicó, Toay, } \\
\text { Trenel, Utracán (PROVINCE OF LA PAMPA); General Alvear (PROVINCE OF MENDOZA); Aluminé, } \\
\text { Añelo, Catán Lil, Chos Malal, Collón Cura, Confluencia, Huiliches, Lácar, Lonconpué, Los Lagos, } \\
\text { Ñorquín, Pehuenches, Pícun Leufú, Picunches, Zapala (PROVINCE OF NEUQUÉN); 25 de Mayo, } 9 \\
\text { de Julio, Adolfo Alsina, Avellaneda, Bariloche, Conesa, El Cuy, General Roca, Ñorquinco, Pichi } \\
\text { Mahuida, Pilcaniyeu, San Antonio, Valcheta (PROVINCE OF RÍO NEGRO); Gobernador Dupuy } \\
\text { (PROVINCE OF SAN LUIS) }\end{array}$ & 1.68 \\
\hline 5 & $\begin{array}{l}\text { Capitán Sarmiento, Carmen de Areco, Chivilcoy, General Rodríguez, Lobos, Luján, Merlo, Navarro, } \\
\text { Salto, San Andrés de Giles, San Antonio de Areco, Suipacha (PROVINCE OF BUENOS AIRES) }\end{array}$ & 1.57 \\
\hline 6 & $\begin{array}{l}\text { Almirante Brown, Brandsen, Esteban Echeverría, Ezeiza, Presidente Perón, San Vicente } \\
\text { (PROVINCE OF BUENOS AIRES) }\end{array}$ & 1.50 \\
\hline 7 & $\begin{array}{l}\text { Andalgalá, Antofagasta de la Sierra, Belén, Santa María, Tinogasta, (PROVINCE OF CATAMARCA); } \\
\text { Cachi, Cafayate, Chicoana, La Poma, La Viña, Molinos, Rosario de Lerma, San Carlos (PROVINCE } \\
\text { OF SALTA); Tafí del Valle, Trancas (PROVINCE OF TUCUMÁN) }\end{array}$ & 1.36 \\
\hline 8 & $\begin{array}{l}\text { Calamuchita, Minas, Pocho, Río Cuarto, San Alberto, San Javier, Santa María (PROVINCE OF } \\
\text { CÓRDOBA); General Juan F. Quiroga, General Ocampo, General San Martín, Rosario Vera } \\
\text { Peñaloza (PROVINCE OF LA RIOJA); La Paz, Santa Rosa (PROVINCE OF MENDOZA); Ayacucho, } \\
\text { Belgrano, Chacabuco, Coronel Pringles, General Pedernera, Junín, La Capital, Libertador } \\
\text { General San Martín (PROVINCE OF SAN LUIS) }\end{array}$ & 1.25 \\
\hline 9 & $\begin{array}{l}\text { General San Martín, Marcos Juárez, Río Primero, Río Seco, Río Segundo, San Justo, Tercero Arriba, } \\
\text { Unión (PROVINCE OF CÓRDOBA); Diamante, Paraná (PROVINCE OF ENTRE RÍOS); Belgrano, } \\
\text { Castellanos, Iriondo, La Capital, Las Colonias, San Cristóbal, San Jerónimo, San Justo, San Lorenzo, } \\
\text { San Martín (PROVINCE OF SANTA FE); Rivadavia (PROVINCE OF SANTIAGO DEL ESTERO) }\end{array}$ & 1.24 \\
\hline
\end{tabular}

